\title{
Рождение идеи индийской истории (к пониманию «Краткого очерка древних и современных границ и истории Индии» Раммохана Рая)
}

\begin{abstract}
Аннотачия: читателям журнала представлен русский перевод «Краткого очерка древних и современных гранич и истории Индии» Раммохана Рая. Этот очерк автор статьи-предисловия к переводу интерпретирует как текст-символ первоначального развития исторического сознания в Индии Нового времени и рождение идеи индийской истории. Написанный «отиом современной Индии», философом, реформатором, родоначальником эпохи Бенгальского Ренессанса (XIX - начало XX в.) Раммоханом Раем, «Краткий очерк» показывает, что его автор мыслит обо всей Индии и её истории, об общеиндийских проблемах. Поэтому этот текст является частью феномена «Открытия Индии» (Дж. Неру), создающего образ родной страны для индийщев и всего мира и интеграчии этого образа в современный мир. Раммохан Рай открыл Индию как сочиокультурное пространство с древним духовным и культурным обликом, как субконтинент, оббединивиий различные «страны» и «районъ», и как большое общество, имеющее свою историю.
\end{abstract}

Annotation: The Russian translation of "A Brief Sketch of the Ancient and Modern Boundaries and History of India," by Rammohun Roy, is presented. This sketch is interpreted by the author of the article-preface for the translation as a textsymbol of the initial development of historical consciousness in Modern India and the birth of the idea of Indian History. Written by "Father of Modern India," philosopher and reformer, founder of the Bengal Renaissance (XIX-early XX century) Rammohun Roy, "A Brief Sketch" shows that its author was thinking about India as a whole and its history and allIndia problems. That is why this text is part of the "Discovery of India" (J. Nehru) phenomenon, creating an image of the native country for Indians and the rest of the world as well as integration of this image in the Modern World. Rammohun Roy had discovered India as sociocultural space, with ancient spiritual and cultural image, and as subcontinent, which has united different "countries" and "districts," as a large society having its own history.

Ключевые слова: история, Индия, Раммохан Рай, Англия, колониализм, развитие, время, общество, инстиmуты, прогресс.

Key words: history, India, Rammohun Roy, England, colonialism, development, time, society, institutes, progress.

\section{ПРЕДИСЛОВИЕ К ПЕРЕВОДУ.}

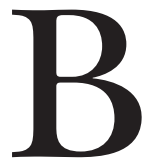
истории мысли и культуры различных обществ есть тексты, которые являются символом начала эпохальных событий в жизни народа и трансформационных процессов в его сознании. Порой эти тексты требуют особых герменевтических приёмов для открытия смысла, скрытого между лаконичных строк, открытия того, что, по мысли Х. Г. Гадамера, «хотело в тексте сказаться». К таким текстам-символам относится «Краткий очерк древних и современных границ и истории Индии» Раммохана Рая.

Философа, религиозного и социального реформатора и общественного деятеля Раммо- хана Рая (1772-1833) часто называют «Отцом современной Индии», воздавая дань его культуротворческой деятельности по теоретическому обоснованию и практической реализации идеи гармоничной интеграции Индии в мир современности (modernity). Не менее Раммохан Рай является творцом эпохи национально-культурного возрождения в колониальной Индии ХІХв., начиная с самой развитой её провинции Бенгалии ${ }^{1}$. В его трудах сформированы ведущие

\footnotetext{
${ }^{1}$ См. об этой социокультурной эпохе: Скороходова Т. Г. Бенгальское Возрождение. Очерки истории социокультурного синтеза в индийской философской мысли Нового времени. СПб., 2008; Bhattacharjee K. S. The Bengal Renaissance: Social and Political Thought. New Delhi, 1986; Dasgupta Subrata. The Bengal Renaissance: Identity and Creativity from Rammohun Roy to Rabindra-
} 
идеи, касающиеся духовного, социального, культурного, политико-правового и экономического развития страны, - идеи, на которые опирались несколько поколений его духовных наследников в индийских интеллектуальных элитах. В этом смысле сама «эпохальная» фигура Раммохана Рая делает любой написанный им текст значимым и требующим обстоятельного изучения.

«Краткий очерк» был написан Раммоханом Раем летом 1831 года, во время его пребывания в Лондоне. Ещё в годы службы помощником британского сборщика налогов в Ост-Индской компании (1805-1813) Раммохан глубоко заинтересовался Западом, особенно его историей, культурой и политическими системами, симпатизировал либерализму и всегда следил за успехами политических реформ и революций в странах Европы. Он первым из индийцев Нового времени отбросил предубеждения перед другими странами и народами и неприязнь к Западу и открыл своё сознание пониманию Других, не-восточных культур 2. У него был план посещения Англии для обучения в одном из её университетов, однако в тот период идея «Паломничества в страну Запада» ${ }^{3}$ не была воплощена: Раммохан поселился в Калькутте и занялся реформаторскими трудами. «...Сообщаю Вам, что некоторые из моих соотечественников поднялись выше своих предубеждений; многие склонны к поиску истины, и многие из числа тех, кто расходился со мной во мнениях, теперь соглашаются со мной, - писал он Джону Дигби. - Эти мои занятия не позволяют мне приехать в Европу, как я ранее мог того желать...» 4 .

К моменту создания «Краткого очерка» Раммохан Рай перевёл с санскрита и издал на бенгали и английском священные тексты индийской традиции (Упанишады) и заявил о необходимости устранить идолопоклонство в формах индуистского богослужения ради вос-

$\overline{\text { nath Tagore. Delhi, 2007; Justyński Janusz. Mysl Spoleczna i Politiczna }}$ Renesansu Indyiskiego, od Rama Mohana Raya do RabindranataTagora. Warszawa etc., 1985; Kopf D. British Orientalism and Bengal Renaissance. Berkeley, 1969; Kopf D. BrahmoSamaj and Making of Modern Indian Mind. Princeton, 1979; Poddar A. Renaissance in Bengal. Quests and Confrontations. 1800-1860. Simla, 1970; Poddar A. Renaissance in Bengal. Search for Identity. 1860-1919. Simla, 1977; Sarkar Susobhan. Bengal Renaissance and Other Essays.

${ }^{2}$ См. Об этом главу в книге: Halbfass $W$. India and Europe. An Essay of Philosophical Understanding. Albany, 1988.P/ 197-216.

${ }^{3}$ См.: Рашковский Е. Б. Научное знание, институты науки и интеллигенция в странах Востока XIX-XX вв. М., 1990. С. 66; Скороходова Т. Г. “Паломничество в страну Запада" в опыте мыслителей Бенгальского Ренессанса // Вопросы философии. 2011. № 11. C. 163-173.

${ }^{4}$ Roy Raja Rammohun. The English Works / Ed. by J.C. Ghose. In 4 vols.NewDelhi, 1982.Vol. I. P. 929. становления строгого монотеизма древности и высокой этики в родной религии, выдержал напряжённую полемику с христианскими миссионерами, защищая от их нападок индуизм и своё понимание христианства и учения Христа; вёл активную просветительскую деятельность, отстаивая необходимость развивать современное европейское образование и науку в Индии, внёс вклад в становление индийской прессы на местных языках (бенгали и фарси) и борьбу за свободу печати и отмену цензуры, успешно провёл общественную кампанию за запрет обычая самосожжения вдов (сати), завершившуюся в 1829 г. принятием соответствующего закона Правительством Ост-Индской компании, - невзирая на непрекращающееся противодействие брахманской ортодоксии, и основал религиозно-реформаторское общество «БрахмоСамадж» (1828), первым стал бороться за права женщин и критиковать индуистскую кастовую систему.

В конце 1829 г. Раммохан Рай снова решает посетить Европу, благо, с одной стороны, он многого добился в своих реформаторских трудах, с другой - появляется новый весомый повод: общество «ДхармоШобха», созданное ортодоксальными индуистами высоких каст для противодействия «посягательствам на религию (дхарму)», отправило в британский парламент петицию с требованием отменить запрет сати ${ }^{5}$. Узнав о том, что Раммохан Рай собирается ехать в Англию, император Акбар II, номинально правивший в бывшей столице Великих Моголов Дели, решил сделать его своим посланником (эльчи) и даровал ему титул раджи, дабы он представлял его интересы в Лондоне. Акбар II считал, что Совет Директоров Ост-Индской компании ущемил его права, урезав расходы на ежемесячное содержание императора, его двора и «войска» и просил британского монарха восстановить справедливость ${ }^{6}$. «...Меня не беспокоят титулы и звания, но я всё же не отказался от этого, чтобы воспользоваться честью, которую мне оказал Его Величество» ${ }^{7}$, - писал Раммохан Рай генерал-губернатору У. К. Бентинку с просьбой признать его новый титул и должность посланника могольского двора. Однако Совет при

\footnotetext{
${ }^{5}$ См.: Скороходова Т. Г. Раммохан Рай, родоначальник Бенгальского Возрождения (Опыт аналитической биографии). СПб., 2008. С. 257, 297-299. Усилия «ДхармоШобхи» успехом не увенчались, т. к. 11 июля 1833 г. судьи Королевского Совета отклонили эту петицию.

${ }^{6}$ Cм.: Petition of Akbar II, Mughal Emperor of Delhi // Collet S.D. The Life and Letters of Raja Rammohun Roy. P. 480-485.

${ }^{7}$ Цит. по: Collet S. D.The Life and Letters of Raja Rammohun Roy.P. 279.
} 


\section{Исторический журнал: научные исследования № 5 (17) • 2013}

\section{DOI: $10.7256 / 2222-1972.2013 .5 .9064$}

генерал-губернаторе не санкционировал такого «своеволия» делийского правителя, и Раммохан Рай 19 сентября 1830 года отправился в Англию как частное лицо ${ }^{8}$.

Резонанс от посещения Раммоханом Раем Англии оказался, тем не менее, велик; и королевские министры, и высшие чиновники ОстИндской компании defacto признали его - представителя завоёванного народа Индии - как посланника этой страны ${ }^{9}$, а британский монарх Уильям IV удостоил его 7 сентября 1831 г. аудиенции в Букингемском дворце. Признание Раммохана Рая высшими кругами Лондона позволило привлечь его в качестве эксперта по британской политике в отношении Индии.

В феврале 1831 года кабинет министров-вигов назначил Избранный комитет для всестороннего анализа деятельности Ост-Индской компании перед очередным возобновлением её Хартии. В июне того же года в Комитете решили пригласить для консультаций Раммохана Рая, который вместо этого 19 августа прислал подробные ответы на поставленные перед ним вопросы. Благодаря болышому личному опыту службы он знал все перипетии судебной и налоговой систем и вместе с тем сам был состоятельным заминдаром ${ }^{10}$. На рассмотрение Парламента и его Избранного комитета Раммохан представил три документа: «Ответы на вопросы о состоянии судебной системы Индии», «Ответы на вопросы о состоянии системы налогообложения» и «Дополнительные вопросы о состоянии народа Индии» (сентябрь 1831). Впоследствии для избранного комитета Раммохан написал обзор преимуществ и отрицательных следствий поселения в Индии европейцев ${ }^{11}$.

Ответам на вопросы был предпослан текст «Предварительные замечания. Краткий очерк древних и современных границ и истории Индии». Почему этот текст - лаконичный, написанный большей частью языком официального доку-

\footnotetext{
${ }^{8}$ Ibid. P. 289. Весьма показательно, что в Манчестере на крупных мануфактурах рабочие приветствовали его как «Короля Индии».

${ }^{9}$ Ibid. P. 316-317.

10 Заминдар - землевладелец. Согласно закону о Постоянном землеустройстве 1793 (Permanent Settlement), введённого маркизом Корнуоллисом, заминдары были признаны частными собственниками своих поместий, обязанными платить налоги Ост-Индской компании, тогда как прежде - при мусульманском правлении, земля принадлежала сюзерену, а заминдарские права предоставлялись за службу, в наследственное владение.

11 Подробно см.: Скороходова Т. Г. Раммохан Рай. С. 265-281; тексты документов см.: Roy Raja Rammohun. The English Works. Vol. II. P. 239-320.
}

мента (личные впечатления автора появляются лишь в заключительной его части и словно не связаны с основным содержанием) - можно расценить как символ?

Прежде всего потому, что перед читателем предстаёт рождение идеи индийской истории. «Краткий очерк» - это специфическая точка отсчёта становления в Индии нового исторического сознания ${ }^{12}$. В самом общем плане это появление и развитие на субконтиненте новых форм сознания и мышления об истории, связанного с научнымисториописанием и философией собственной истории. Эти новые формы развиваются благодаря деятельности новых интеллектуальных әлит, которые - в отличие от традиционных носителей знания и культуры (брахманов) - интенсивно осмысливают свою культуру, общество, положение своей страны в соотнесении с Другими культурами, обществами, странами и регионами. В ходе интеллектуальных усилий, попыток реформирования сфер общественной жизни и развития культуры индийские новые элиты создают подвижный и своеобразный проект развития Индии через синтез её культурных традиций с западными достижениями и новациями. Возникновение новых форм исторического сознания является неотъемлемой частью проекта развития (возрождения через развитие) страны, общества, так как не может быть обоснования перспективы эволюции в будущем без осмысления настоящего и без обращения к прошлому.

Уже в названии «Краткого очерка» заявлены две, а при внимательном рассмотрении - три идеи: идея ограниченного определёнными рубежами пространства (субконтинент), идея истории Индии и собственно идея Индии.

«Индия сама по себе - это целый мир, она представляет собой общество не меньшей величины, чем наше западное, - писал британский историософ и культуролог А. Дж. Тойнби. - И в то же время это единственное значительное незападное общество, которое не просто подверглось нападению, но было захвачено и разграблено силой западного оружия, и не только захвачено, но надолго осталось под властью западных правителей» 13 . Действительно, «общество», называемое Индией, - это масштабный субконтинент, по разнообразию народов и регионов, культур

\footnotetext{
${ }^{12}$ Скороходова Т. Г. Историческое сознание Бенгальского Возрождения (историко-философский анализ) // Восток. 2009. № 1. С. 76-87

13 Тойнби А. Дж. Цивилизация перед судом истории. М.-СПб., 1996. С., 170.
} 
и верований не уступающий другому подобному субконтиненту - Европе. В отечественной индологии подробно показано, что «на протяжении всего доколониального периода истории индийцы не воспринимали свой субконтинент как единое целое и не выработали, при всём языковом богатстве, даже названия, аналогичного современному понятию “Индия" " ${ }^{14}$, хотя жители определённых регионов и были привязаны к своим землям (независимо от конфессиональной принадлежности) и хорошо различали «своих» и «чужих» ${ }^{15}$, а между областями существовали разного рода взаимодействия и связи - от религиозных движений до политических объединений. Создание Британской Индийской империи, растянувшееся почти на сто лет, стало defacto(а формально-юридически - исключая около 600 княжеств, признававших британского монарха своим сюзереном) объединением в политическое целое всего субконтинента и утвердило для него название «Индия». В восприятии же иностранцев Индия также не была единым целым; как восточные, так и западных путешественники называют её земли Индиями - в т. ч. и британцы (ХІХв.) ${ }^{16}$.

Раммохан Рай, в юности странствовавший по индийским регионам (маршруты его путешествий практически неизвестны), знал на собственном опыте эту особенность традиционной страны. Житель региона, первым завоёванного британцами, в своих трудах индийского периода он критиковал прежде всего те пороки и противоречия, которые видел в Бенгалии, но также приводил реалии других областей. И всё же именно у него появляется идея Индии в обозначении своей родины, а в документах для парламента ${ }^{17}$ он представляет описание судебной и налоговой систем в других индийских президентствах. Нетрудно предположить, что он воспринял термин «Индия» от британских властей и европейских учёных-ориенталистов ${ }^{18}$. Но, думаю, здесь не обошлось без влияния мусульманского образования,

\footnotetext{
${ }^{14}$ Ванина Е. Ю. Исторический обзор // Индия: страна и её регионы. Под ред. Е. Ю. Ваниной. М., 2000. С. 21.

${ }^{15}$ См.: Ванина Е. Ю. Средневековое мышление: индийский вариант. М., 2007. С. 58-76.

${ }^{16}$ Там же. С. 61.

17 Из всех названий работ Раммохана Рая слово «Индия» в заглавиях впервые появляется в группе документов для парламента - начиная с «Краткого очерка».

${ }^{18}$ Другим столь же распространённым термином стал термин «индуизм», введённый в XVIII - XIX вв. для обозначения всего комплекса верований субконтинента. См.: Штитенкрон Г. фон 0 природе индуизма. 0 правильном употреблении обманчивого термина // Древо индуизма. М., 1999. С 247-249.
}

полученного юным Раммоханом Раем в Патне (г. Бихар): вместе с традиционными дисциплинами он усвоил и понятие «Хинд» («Хиндустан») как мусульманское обозначение территории, населённой не-мусульманами/индусами ${ }^{19}$. Так западно-восточные влияния на Раммохана определили его выбор названия для целого субконтинента, и это название его духовные наследники начнут весьма интенсивно наполнять содержанием - во многом по тем векторам, которые наметил филоcoф. В этом плане его можно назвать и «отцом понятия Индии» - для индийцев.

Соответственно обе идеи, заложенные в названии, конституируются понятием Индии 20 : это и пространство, отделённое от других подобных пространств естественными границами и характеризующееся определёнными культурными особенностями, и история этого пространства от древности до современного положения.

О том, как рождение идеи индийской истории связано с присвоением и усвоением понятия Индии, в её территориально-пространственном и социокультурном выражении, свидетельствует структура «Краткого очерка».

Раммохан Рай начинает с описания границ и естественных регионов Индии и сложившегося в древности деления «Бхаратварши» (букв.«Земля потомков Бхараты») на «культурную и священную», «культурную» и области млечиха (варваров), затем кратко рисует мусульманское правление в Индии, говорит о переходе южных, восточных и западных земель под власть Ост-Индской компании и особенностях становления правления британцев и завершает очерк замечаниями личного плана, на первый взгляд, не связанными с предшествующим содержанием - о своих позитивных впечатлениях от Европы и устремлениях. Два смысловых раздела - о социокультурном пространстве и ходе его истории подчёркнуто «объективны», в отличие от третьего (заключительного), где личность автора и его отношение к Европе выходят на первый план.

Содержание трёх разделов вполне схематичное, больше похожее на эскиз, чем на очерк-

\footnotetext{
19 Первое употребление термина «Индия» (в персидском варианте - как «Хиндустан») встречается к первому трактату Раммохана Рая «Дар верующим в Единого Бога». См.: Раммохан Рай. Дар верующим в единого Бога. Перевод с английского, примечания Т. Г. Скороходовой // Вопросы философии. 2010. № 11. С. 162, 165

20 Раммохан пользуется словом «индийцы» (вариант «народ Индии») для обозначения населения субконтинента, и имеет в виду и индусов, и мусульман. См. например: Roy Raja Rammohun. The English Works. Vol. II. P. 295-298.
} 


\section{Исторический журнал: научные исследования № 5 (17) • 2013}

\section{DOI: $10.7256 / 2222-1972.2013 .5 .9064$}

описание, окажется объёмным и сложным, если учесть и контекст его создания, и личность автора. Тогда за каждым разделом и структурной единицей «Краткого очерка» обнаружатся значения и смыслы, уже артикулированные в предшествующих этому тексту работах Раммохана Рая. Из смыслов и вырастает идея индийской истории.

Естественные границы Индии - это природное условие бытия её населения как народа, общности, общества и субконтинента. Петербургский индолог М. Ф. Альбедиль справедливо замечает, что природа диктует «свои законы истории, типу культуры и типу личности», и сравнивает в этом смысле Индию с Россией, которая, по словам П. Я. Чаадаева, есть «факт географический», который «властно господствует над нашим историческим движением». В значительной степени «фактом географическим» является и Индия: жизнь людей и жизнь природы соединялась в ней множеством тонких и сложных связей» ${ }^{21}$, - заключает учёный. Раммохан Рай в «Кратком очерке» подробно останавливается на географических границах субконтинента и - на внутренних межрегиональных границах, дробящих структуру индийских земель и затрудняющих взаимодействие между их народами.

Индия с древности и до современности для Раммохана является в первую очередь особым духовно-культурным пространством, которое организовано «сходными» религиозными представлениями («религиозными принципами»), их культовым воплощением («общепризнанные ритуалы и церемонии») и общим языком священного текста - санскритом ${ }^{22}$. Духовный мир Индии, особым образом предопределённый её географией, есть определяющий смысл её бытия и движения во времени.

Санскритское образование Раммохана Рая, его работа по переводу и новому истолкованию Упанишад и всей религиозной традиции побудили его обозначить три ведущих компонента духовного единства - вера, традиция и священный язык. Это духовное единство субконтинента претерпевает в истории испытания как социальноструктурного, так и социально-психологического плана. О первых Раммохан говорит в «Кратком очерке» - вражда правителей, представление брахманского священства о большей или меньшей «культурности/цивилизованности» частей индийского географического пространства, ка-

\footnotetext{
${ }^{21}$ Альбедиль М. Ф. Индия: беспредельная мудрость. 2-еизд. М., 2005. С. 24.

${ }^{22}$ Roy Raja Rammohun. The English Works. Vol. II. P. 231.
}

стовость и секты; социально-психологическим аспектам разобщённости посвящены его религиозно-реформаторские работы, в которых он говорит о деградации высокого представления о Едином Боге и развитии веры в многочисленных богов («идолов» - здесь напрашивается параллель с терминологией чтимого Раммоханом Ф. Бэкона) и связанных с ним обрядоверием, суевериями, предрассудками и ограничениями, которые искусно подогреваются брахманами из века в век ${ }^{23}$.

По сути, древний (до мусульманского завоевания ряда областей) период Раммохан не показывает как историю Индии: в содержании «Краткого очерка» она выглядит процессом дробления субконтинента на царства, враждующие друг с другом, и увеличения кастовой и религиозно-социальной дифференциации, ломающих самую структуру социального и политического единства страны.Он даже не упоминает периоды крупных империй (Маурья (320-185 гг. до н. э.), Гупта (320-497 гг. н. э.)), когда индийские земли объединялись под властью сильных династий, - думается, не только по причине малой их изученности, но и желания подчеркнуть, как дробление социальной и политической структуры подрывало духовно-культурные основы жизни и разобщало население, делало даже соседствующие области чужими друг другу ${ }^{24}$. Неудивительно, что краткое определение Индии как «страны, в которой понятие патриотизма никогда не возникало» 25 - это беспощадный вердикт Раммохана соотечественникам, замкнутым на себе самих и безразличных к Другому - даже своему, не говоря уже о других странах и регионах.

«Совершенно очевидно, что основная проблема Индии - проблема единства, - говорил Рабиндранат Тагор в 1833 г. на митинге памяти Раммохана Рая в Калькутте. - Здесь сошлось множество рас - в этом отношении другой такой страны нет во всём мире. Объединить все эти народы, причём объединить не снаружи, а изнутри - вот главная задача Индии» 26. Раммохан Рай, по мысли его великого духовного наследника, был поборником именно такого единства и «показал лицо другой, подлинной Индии» в противовес «Индии, погрязшей в сектантской

\footnotetext{
${ }^{23}$ См.: Скороходова Т. Г. Раммохан Рай. С. 74-88, 106-124.

${ }^{24}$ В индийских языках это разграничение-разделение отражено довольно чётко: deśi - житель нашей земли, «свой»; videśi житель соседней земли, «не свой», pardeśi - чужой, чужеземец.

${ }^{25}$ Roy Raja Rammohun. The English Works. Vol. I. P. 233.

${ }^{26}$ Тагор Р. Собрание сочинений в 12-ти тт. М., 1961-1964. Т. XI. C. 306.
} 
ограниченности, всеобщей продажности и невежестве» ${ }^{27}$. И этот смысл - в его социальном облике - заложен в «Кратком очерке»: общий духовный мир древней Индии не породил социального единства в виде солидарности общностей и культурных кругов; напротив, дробность социальной структуры и политического пространства Индии делали её уязвимой как изнутри (для бесчисленных междоусобиц), так и извне, для иностранных завоевателей.

На первый взгляд, схематическое деление практически без датировок - индийского исторического времени на периоды (древний (княжеств и государств), мусульманского и затем британского завоевания) повторяет общую схему «Истории Британской Индии», вышедшей в 1817 году и принадлежавшей перу лондонского чиновника Ост-Индской компании, философа-утилитариста Джеймса Милля (1773-1836). Он прямолинейно изобразил в тёмных красках добританский период и заявил, что история Индии начинается только с приходом англичан ${ }^{28}$.Однако несмотря на широкую осведомлённость Раммохана Рая о трудах британских историков об Индии (к ним он отсылает всех, кому интересны подробности британского завоевания; в их числе и книга Милля), его деление истории Индии не столь однозначно и не являет кальку с периодизации Милля.

История Индии у Раммохана разделена на два периода - древний, содержанием которого оказалась дифференциация и разобщение, и эпоха завоевания, - подчинения мусульманским, а затем британским правителям всё больших областей субконтинента. В очерке мыслитель говорит только о современной ситуации, но никак не о будущих перспективах Индии. Но далее, в основных документах для парламента он намечает перспективу британского правления: поскольку в современной Индии сложился слой экономически активных собственников и коммерсантов, которые «реально рассматривают его (существующее правление. - Т. С.) как благо для страны», то «единственным курсом политики, который может обеспечить их поддержку любой формы правления, должно быть предоставление им воз-

\footnotetext{
27 Там же. С. 311.

28 Такая трактовка уже в 1820-х гг. вызвала критику молодых калькуттских интеллектуалов; Кашипрошад Гхош аргументированно опроверг рассуждения Милля об однообразном чередовании «варваров-тиранов» и об индусах-«невежественных варварах» (См.: Kopf D. British Orientalism and Bengal Renaissance. Berkeley, 1969. C. 263-264; Скороходова Т. Г. Младобенгальцы. Очерки истории социальной мысли Бенгальского Возрождения (Первый период, 1815-1857). СПб., 2012, 191-192.
}

можности постепенного продвижения, в соответствии с их способностями и качествами, на ответственные и уважаемые государственные должности» ${ }^{29}$. В другом месте он говорит о создании смешанной структуры управления Индией, где действуют «способные туземцы» вместе с британцами или отдельно от них, и даже - в перспективе предвидит независимость Индии - но после того, как она с помощъю Европь добьётся выхода «на уровень европейских христианских стран» ${ }^{30}$.

С мусульманского и особенно британского завоевания обозначается проблема политической организаиии управления Индией: мусульманские династии были склонны к неограниченной власти, и по мере упадка государства «чаще руководствовались своим личным благополучием, нежели благосостоянием государства» 31 , а британцы, несмотря на злоупотребления властью и смешанную первоначально систему управления («европейско-азиатскую») стремятся к рациональному осуществлению власти над индийскими владениями, приближая её «к институтам, существующим в Англии» 32 . Современи борьбы за свободу прессы Раммохан Рай показал себя стойким сторонником конституционно-правового порядка и политических свобод, принципа строгого разделения властей и «просвещённого правления», и потому его позиция в «Кратком очерке» вполне взвешена: «сомнительный характер средств, которыми были получены её (Англии. - Т. С.) приобретения и осуществлены завоевания» 33 очевиден, но институциональные и административные нововведения вполне могут обернуться социально-политическими преимуществами для субконтинента.

Поэтому следующее за этим восхищение Раммохана развитием наук, знания, культуры и политики в Европе, а также интерес к нравам и обычаям, «добродетелям и выдающимся качествам женщин» 34 - это указание на состояние общества, которого Раммохан желал бы для Индии - её динамичного развития в мире. Через неявное сопоставление (без сравнения) Индии и Европы, двух субконтинентов, Других по отношению друг к другу миров, философ полагает куль-

\footnotetext{
${ }^{29}$ Roy Raja Rammohun. The English Works. Vol. II. P. 300.

${ }^{30}$ Ibid. P. 268, 316.

${ }^{31}$ Ibid. Vol. I. P. 233.

${ }^{32}$ Ibid. P. 236.

${ }^{33}$ Ibid. P. 234

${ }^{34}$ Ibid. P. 236.Последнее особенно показательно в свете глубокой озабоченности Раммохана Рая положением женщин в Индии и его социально-реформаторской деятельностью, касающейся прав женщин на жизнь и имущество.
} 


\section{Исторический журнал: научные исследования № 5 (17) • 2013}

\section{DOI: $10.7256 / 2222-1972.2013 .5 .9064$}

турно-просветительский смысл текущей истории своей страны, управляемой британцами, и смысл её будущей истории: понимать и осваивать Другое - культуру, науку, литературу, духовные традиции, этику, институты - чтобы восстановить прежнее духовное единство, социально и политически интегрировать раздробленное и разобщённое население, и сделать это через диалог с окружающим миром, через понимание самих себя в этом диалоге. Ранее, в 1823 г. в Петиции в защиту свободы печати Раммохан Рай отмечал, что «...при власти этой нации (британской. T. С.) будут произведены как духовные, так и социальные усовершенствования, и жизнь, религия и имущество местного населения будут под защитой» ${ }^{35}$. Вместе с тем он предвидел историческую перспективу независимости Индии, но прежде, как он сформулировал в беседе с В. Жакемоном, «потребуется намного больше лет английского господства, чтобы она не смогла утратить многое из приобретенного, прежде чем она потребует вернуть свою политическую независимость» 36 .

Именно современное состояние Индии в сопоставлении с динамикой истории Европы является для Раммохана решающим аргументом в пользу оптимистического видения её перспектив - на пути, с одной стороны, усвоения нового, современного в сфере социальных отношений, политики, культуры, с другой же - сохранения, а если потребуется, и возрождения духовной традиции и культуры вместе с критическим отношением к общепринятым установлениям и институтам, перестающим отвечать требованиям современности.

В заметке Раммохана об истории Индии нет и следа традиционных циклических представлений об истории как регрессивном упадке дхармы, как нет и фрагментированного отождествления истории Бенгалии с историей всей Индии 37 . С одной стороны, он продолжает традиционный для регионов Индии векторный (линейный) подход к моделированию исторического времени 38 и распространяет его на весь субконтинент в

\footnotetext{
${ }^{35}$ Roy Raja Rammohun. The English Works. Vol. II. P. 439.

${ }^{36}$ Collet S. D. (and Stead F. H.) The Life and Letters of Raja Rammohun Roy.P. 386.

${ }^{37}$ Внимание к государству Ранджита Сингха на Северо-Западе Индии - показательный признак восприятия субконтинента Раммоханом Раем.

38 У традиционных авторов, фиксировавших исторические события, история была историей правления отдельных раджей или региональных династий, подобно кашмирской исторической хронике в стихах «Раджатарангини» («Река царей») (завершена в 1147-1148 г. поэтом Калханой).
}

целом. С другой стороны, влияние европейского прогрессистского историзма и британских ориентальных исследований побуждают Раммохана критически смотреть на прошлое своей страны и благодаря этому наметить тему исторического своеобразия Индии (дробность социальной и политической организации, уязвимость перед внешними завоеваниями, недостаток патриотизма и солидарности), а также показать самое возможность прогресса как развития во времени. Намечается у него и тема возрождения страны как ближайшей цели индийской истории (в этом он апеллирует не только к соотечественникам, но и к британцам, которые могут способствовать этому своей «просвещённой» политикой), а также тема социокультурного единства страны.

«Краткий очерк» свидетельствует прежде всего о том, что его автор-бенгалец, преодолев особенности традиционного «регионалистского» мышления, мыслит обо всей Индии. Поэтому факт появления текста - вернее, группы текстов - с освещением общеиндийских вопросов и специфики можно расценить как возникновение феномена открытия Индии (термин Дж. Неру). Феномен открытия родной страны, характерный для разных социокультурных ареалов в Новое время, представляет собой обращение интеллектуалов к осмыслению своей страны и её прошлого для понимания себя самих (в том числе перед лицом Другого) и для создания определённого образа своей страны для себя и для других и «вписывания» этого образа в современный мир.

Раммохан открывает Индию как социокультурное пространство, с древности имевшее сходный духовный («религиозные принципы») и культурный облик, как субконтинент, географически объединяющий разнообразные «страны» и «районы», и как большое общество (или общество-субконтинент), эволюционирующее во времени, т. е. имеющее историю.

За лаконичным обозначением вех индийской истории, как позволяет заключить герменевтический анализ текста, у Раммохана Рая скрыта идея индийской истории. В историческом времени Индия движется из древности в современность, в которую её вовлекает британское завоевание и начинающийся диалог с Западом. Общий ход её истории выглядит в очерке Раммохана как своеобразное испытание и преодоление. Пространственные границы, вражда правителей и социальные перегородки («касты и секты») не способствовали развитию межрегионального взаимодействия, солидарности и 
чувства патриотизма, и поэтому разобщённые земли в конце концов стали добычей сначала мусульманских завоевателей, затем британских колонизаторов. Это испьтание иностранным правлением, особенно - Ост-Индской компании, тем не менее, объединяет страны и регионы извне, чем косвенно создаёт условия для преодоления разобщённости и взаимодействия регионов Индии. Однако собственно преодоление, судя по тексту и контексту его создания, лежит в сфере, во-первых, преодоления культурного эксклюзивизма индийских брахманских элит в отношении разных групп, особенно социальных низов, преодоление кастовых ограничений и предрассудков, невежества населения, гендерного неравенства, а также преодоления произвола власти и бесправия основной массы населения, а во-вторых, на пути освоения и развития институтов и достижений европейской цивилизации (прежде всего в сфере просвещения и политики). И лишь после этого, в отдалённой перспективе, будет возможно требование вернуть Индии независимость.

В таком виде идея индийской истории у Раммохана Рая выступает контраргументом Дж. Миллю и - шире - ряду европейских мыслителей, убеждённых в том, что у Индии нет истории. Из этого опровержения европейского восприятия индийской истории выросла традиция индийской историографии XIX - ХХІвв.

От этого рождения идеи индийской истории меньше десятилетия остаётся до первых исторических штудий группы учеников Г. В. Л. Дерозио (младобенгальцев) в рамках «Общества содействия приобретению всеобщих знаний» (1838-1842) ${ }^{39}$, последовавших призыву КришномоханаБанерджи изучать историю своей страны, а также - до эпохального выступления СурендронатхаБанерджи «Исследование индийской истории», где само изучение истории страны обозначено как условие возрождения Индии ${ }^{40}$.

Британское завоевание и правление стало особым рубежом, потребовавшим от новых индийских интеллектуальных элит оглянуться за своё прошлое, чтобы истолковать настоящее. В этом смысле первый взгляд оказавшегося в метрополии индийца на свою родину явился символической точкой отсчёта становления исторического сознания бенгальского Ренессанса и в целом современной Индии.

\footnotetext{
${ }^{39}$ Скороходова Т. Г. Младобенгальцы. С. 180-205.

40 См.: Банерджи Сурендронатх. Исследование индийской истории / Перевод с английского Т. Г. Скороходовой // Вопросы философии. 2012. № 9. С. 144-156.
}

\section{Раммохан Рай \\ Краткий очерк древних и современных границ и истории Индии ${ }^{41}$}

Индия, с древности называемая «Бхарат-варша» 42 по имени царя, названного Бхаратой ${ }^{43}$, на юге ограничена морем, на востоке - частично этим же морем, частично - горными хребтами, отделяющими её от древнего Китая, или, точнее, районами (countries), теперь называемыми Ассамом, Кассеем и Араканом [1]; на севере - обширными и величественными цепями гор, которые отделяют её от Тибета; и на западе частично хребтами гор, отделяющими Индию от Персии и простирающимися до Западного моря [2] над устьем Инда, и частично самим этим морем. Она простирается между 8 и $35^{\circ}$ северной широты и 67 и $93^{\circ}$ восточной долготы ${ }^{44}$.

Обширные пространства этой империи (empire)[3] ранее управлялись различными отдельными князьями, которые хотя и были независимы и враждебны друг другу, придерживались сходных религиозных принципов, в общем соблюдали общепризнанные ритуалы и церемо-

\footnotetext{
${ }^{41}$ Перевод выполнен по изданию: Roy Raja Rammohun. The English Works / Ed. byJ. C. Ghose. In 4 vols. New Delhi, 1982. Vol. I., P. 231. Примечания Раммохана Рая даны в постраничных сносках, примечания переводчика - в конце текста.

42 «Варша» означает большую часть пространства континента, отрезанную от других стран естественными границами, такими как океаны, горы или обширные пустыни.

43 Бхарата - человек и могущественный князь, как предполагается, происходит из Инду-вансы, или Лунной династии.

44 Пограничные горы прерываются на востоке между 90 и $91^{\circ}$ восточной долготы и 26 и $27^{\circ}$ северной широты. Отсюда районы к востоку от Брахмапутры - Ассам, Ава, Сиам и др. вплоть до $102^{\circ}$ восточной долготы некоторыми авторами рассматриваются как часть Индии, хотя и за её естественными границами; и Европейские авторы обычно называют их «Индией за Гангом». Здесь до сих пор находят реликвии санскритской литературы и руины индуистских храмов. Другие древние писатели, тем не менее, считают эти страны примыкающими к Китаю, и население внешним обликом весьма похоже на китайцев.

Западные пограничные горы с виду подобны длинным разломам с $70^{\circ}$ восточной долготы и $37^{\circ}$ северной широты. Следовательно, страны, лежащие за естественными границами, такие как Кабул и Кандагар, некоторые считают принадлежащими Индии, а другие - Персии. Но многие индусские древности до сих пор существую там, чтобы подтвердить первую точку зрения. Не только северные пограничные горы Индии, но также и те горы, которые формируют восточные и западные её границы, авторы, в древности писавшие об Индии, определяли как Гималаи, и считали их ответвления большими горными цепями. «На северном направлении расположен царь гор, бессмертный Хималай, который объемлет и восточные, и западные моря, стоит на востоке как воплощение величия)» - Калидаса[4].
} 


\section{Исторический журнал: научные исследования № 5 (17) • 2013}

\section{DOI: $10.7256 / 2222-1972.2013 .5 .9064$}

нии, обучались на санскритском языке - более или менее строгом. Эти пространства земель были отделены друг от друга реками или горами, или иногда - разграничительными линиями.

Область, именуемая «культурной» ('thecivilized') в священных текстах брахманов, делится на две больших части ${ }^{45}$.

Первая названа «культурной и священной землёй» 46 , которая, простираясь от берегов Инда с $34^{\circ}$ северной широты и $72^{\circ} 25^{\prime}$ восточной долготы, в юго-восточном направлении, вместе с подножием Гималайских гор, до $26^{\circ} 30^{\prime}$ северной широты и $87^{\circ} 30^{\prime}$ восточной долготы, лежит между этой линией и северными границами горной цепи Виндхья, которые продолжаются от $22^{\circ}$ северной широты и $73^{\circ}$ восточной долготы до $25^{\circ}$ северной широты и $87^{\circ} 30^{\prime}$ восточной долготы, через Раджмахал, Бихар, Бенарес, провинции Аллахабада и Мальвы, до северного берега Нербудды [9], почти до западного побережья Индии. Вторая же часть называется просто «культурной землёй» и расположена между Восточным и Западным побережьями, завершаясь к востоку от устья Ганга, около $22^{\circ}$ северной широты и $87^{\circ} 30^{\prime}$ восточной долготы на Востоке и у устья Инда у $22^{\circ}$ северной широты и $72^{\circ} 30^{\prime}$ восточной долготы, охватывая большую провинцию Гуджарат.

Страны, расположенные за границами вышеописанных «культурных земель», будь то горы, долины или низменности, хотя и относятся к Бхаратварше, обозначены как населённые главным образом млечиха[10], или варварами, и, следовательно, называются варварскими областями ${ }^{47}$.

\footnotetext{
45 Ману [5], самый древний авторитетный законодатель, таким образом определяет их границы: «земли, простирающиеся от Восточного и до Западного океанов, и между вышеупомянутыми горами (ХимаватиВиндхья[6]) известны мудрым под именем “Арьяварта”, или “Земля, населённая достойными людьми” (Глава II, стих 22) [7]. В своём переводе этого фрагмента сэр Уильям Джонс, пропустив ссылки и комментарии, которые заменяют соединительную санскритскую частицу 'cha'на 'eba', следующим образом перевёл это предложение: «От Восточного до Западного океанов, между двумя вышеупомянутыми горами, лежит полоса пространства, которую мудрые назвали “Арьявартой” „.Это переведённое описание не ясно, если не в целом непонятно, поскольку страны, лежащие между этими двумя цепями гор, вряд ли расположены между Восточным и Западным морями.

46 Потому что эта часть включает в себя пространство, названное Священной землёй и расположенное к северу от Дели, следующим образом описано Ману: «Между двумя божественными реками Сарасвати и Дришадвати, простирается область, которую святые назвали Брахмавартой, потому что её часто посещали боги» [8]. (Ману, II, 17).

47 Страна, где разделение на четыре класс (Брахманы, Кшатрии, Вайшьи и Шудры) не соблюдается, известны как МлеччхаДеша, или «варварские страны», как это процитировано у Рагхунанданы [11].
}

Вследствие увеличивающихся разделений и субподразделений этой земли на отдельные и независимые царства, находящиеся под властью многочисленных царей, враждующих друг с другом ${ }^{48}$, а также из-за постоянного возникновения обширного количества каст и сект, ломающих самую структуру социального и политического единства страны (или, точнее говоря, её частей, смежных с иностранными землями), она в разные периоды подвергалась вторжениям и попадала во временное подчинение иностранным правителям, прославившимся своим могуществом и честолюбием.

Около 900 лет тому назад мухаммеданские князья, продвинувшись к северо-западу, начали вторгаться и опустошать эту страну [13], и после долгих усилий в продолжение нескольких веков преуспели в завоевании лучших областей Индии. Их правление последовательно переходило от одной династии завоевателей к другой (Газни, Гхор и Афган) [14] до 1525 г. христианской эры, когда князь Бабур [15] - потомок Тимура (или Тамерлана) в четвёртом поколении установил своё престол в центре Хиндустана. Его наследники (Могольская династия) осуществляли неограниченную верховную власть вэтой империи ${ }^{49}$ около двух столетий (исключая около 16 лет), с разнообразными изменениями, соответственно росту или упадку их власти.

В 1712 году звезда Могольской власти стала клониться к закату, и с этого времени постепенно зашла за горизонт. Правители всё чаще руководствовались своим личным благополучием, нежели благосостоянием государства, и наудачу полагались на репутацию своей династии больше, чем на здравую политику и военную доблесть. Не только их престол, но и их жизнь зависели от доброй воли их придворных, которые фактически присваивали себе независимость от своего суверена, и каждый из них искал собственного личного возвышения.

В настоящее время все южные и восточные, так же как и некоторые западные области империи постепенно переходят под власть ан-

\footnotetext{
48 Это сравнимо с состоянием Персии, когда ею правили несколько независимых князей - в противоположность внушительной власти, которой она обладала после объединения в империи Суфиев [12].

Теперь обратите своё внимание на самую близкую вам страну - я имею в виду Англию: и сравните следствия, прежде происходившие из-за разделения её сил (resource) её настоящим состоянием, усовершенствованным при существующем союзе.

49 Её можно обозначить как объединяющую следующие двадцать провинций: Дели, Лахор, Кашмир, Кабул, Кандагар, Аджмер, Мултан, Гуджарат, Агра, Ауд, Аллахабад, Бихар, Бенгалия, Орисса, Мальва, Кхандеш, Берар, Аурангабад, Голконда, Биджапур.
} 
гличан [16]. Армия, которую они использовали, состояла главным образом из местных жителей Индии, - страны, в которой понятие патриотизма никогда не возникало. Эти территории фактически были переданы от огромного числа мятежных аристократов-правителей в британское владение.

В это же время огромная часть северных областей за рекой Сатледж попала в руки Ранджита Сингха, главы племени, которое все называют сикхами [17].

Акбар II [18], современный наследник и представитель императорского дома Тимуридов, носит лишь ничего не значащий титул «Короля Дели», без каких-либо королевских правовых привилегий или власти.

Ранджит Сингх, правитель Северо-Западной Индии (включающей Лахор, Мултан, Кашмир и Восточный Кабул), как считается, высоко одарён благоразумием и выдержкой, и очевидно склоняется к либеральным принципам; он здраво мыслит при исполнении своих общественных обязанностей и любезен в личном общении. Идея конституционного образа правления для его сознания оказалась всецело чуждой, и у него есть необходимость следовать той самой системе самовластного правления, которая веками преобладала в стране. Установленное им правление, хотя и чисто военное, тем не менее, умеренное и умиротворяющее.

Что же касается обстоятельств, при которых группа уважаемых английских коммерсантов (под именем Почтенной Ост-Индской Компании), впервые получившая свою Хартию привилегий в 1600, в правление королевы Елизаветы, чтобы вести торговлю с Восточными Индиями, и с уважением к особенностям их успеха в обеспечении - от императора Хиндустана (Джахангира) [19] и некоторых его преемников разрешения основывать торговые фактории, так же как и пребывание под защитой и разнообразные привилегии в этой стране; в отношении их дальнейших завоеваний, которые начались в середине 18 столетия, распространились на большую часть Индии, - то этим они в первую очередь обязаны вражде и малодушному состоянию местных князей и царьков, равно как и невежеству, существовавшему на Востоке, а также современным усовершенствованиям в области искусства ведения войны, сочетавшимся с могущественной поддержкой, предоставленной Компании со стороны военных и морских сил Английской короны - и я отсылаю читателей к современным историям Индии 50 с деталями и подробностями, которые в данный момент далеки от цели, которую я имею в виду в настоящий момент.

В то же время правительство Англии получало многократные указания на сомнительный характер средств, которыми были получены её приобретения и осуществлены завоевания, и на злоупотребления властью, которой облечены служащие Компании ${ }^{51}$, посылавшиеся время от времени в Индию, чтобы управлять завоёванными территориями; вследствие этого сложилось впечатление, что безмерное, почти неисчислимое расстояние между Индией и Англией, затрудняющее взаимодействие между населением обеих стран, и отсутствие достаточного местного контроля над осуществлением власти чиновниками исполнительной власти Компании, так же как и надежда на поддержку их влиятельными работодателями в Англии, могли привести многих из них к пренебрежению своими обязанностями или их нарушению, и этим опозорить национальный характер. Исходя из таких соображений, Британский Парламент в 1773 г. посредством подписанного королём Георгом III акта, известного как Закон об урегулировании (RegulatingAct), заявил, что все территориальные приобретения, будь то завоёванные или присоединённые по договору, относятся к этому государству; установлено, что вся переписка, связанная с его гражданским или военным правлением, должна подлежать рассмотрению министрами; и соответственно в 1784 (по Закону 24, за подписью короля Георга III (капитул 25)) Корона учредила Палату уполномоченных (BoardofCommissioners) для контроля над деятельностью Ост-Индской компании и чиновников исполнительной власти в Индии [17]. В Палату входят президент, который обычно заседает в британском Кабинете министров, и нескольких членов, уважаемых и прочих, с секретарём и другими необходимыми

\footnotetext{
${ }^{50}$ Брюс «Анналы», Андерсон «История коммерции» (в "Анналах" Макферсона), сэр Томас Роу Журнал и письма, Рейналь «Восточная и Западная Индии», Орм «Исторические фрагменты» и о правительстве и народе Индостана», Доу «История», Малколм «Очерк политической истории Индии» и его же «Центральная Индия», Милль «История Британской Индии» [20].

51 Они были, в основном, родственниками и друзьями ведущих членов Компании, числом двадцать четыре, - называемых «Директорами», впервые избранных в 1709 и общим органом Компании облечённых властью осуществлять управление их территориальными владениями в Индии, так же как и торговлей Востока и Запада.
} 


\section{Исторический журнал: научные исследования № 5 (17) • 2013}

\section{DOI: $10.7256 / 2222-1972.2013 .5 .9064$}

подчинёнными должностными лицами. Это учреждение отвечает цели, которая касается предметов общего характера.

Система управления, введённая чиновниками исполнительной власти Компании и действовавшая в Индии до 1793 г. [22], была смешанного характера, - европейско-азиатская. Установленное обращение со страной было приспособлено для большей её части в качестве модели управления ею во исполнение политических, налоговых и судебных функций с изменениями на усмотрение местных властей. В дополнение к осуществлению суверенной власти - власти, признанной в качестве переданных ей делийским троном полномочий, - они продолжают действовать в своих коммерческих интересах с большим успехом, нежели прежде, до установления их суверенитета ${ }^{52}$.Принимая во внимание обширные территории, приобретённые в различных частях Индии Компанией, она сочла желательным установить три правительства в трёх президентствах - Бенгальском, Мадрасском и Бомбейском; два последних с 1773 являются подчинёнными первому в делах политического характера.

Честный и достойный государственный деятель маркиз Корнуоллис [23] принял управление Бенгалией в 1786 г. ${ }^{53}$ Он преуспел не только в консолидации британской власти в её политических отношениях с этими отдалёнными регионами, но также и во введении в 1793 г. действительных изменений в каждом департаменте, в частности, в доходной (налоговой) и судебной системах. Эти изменения приблизили их к институтам, существующим в Англии, которые считаются действующими с пользой, если их регулярно поддерживать на практике.

Что касается моего свидетельства о Правительстве Индии, которое будет составлять основную часть этого труда, а именно обзор практического действия этих систем [24], я воздержусь от повторения их в этой части.

Время от времени направляя свои занятия на исследование предметов и событий, непосредственно связанных с Европой, и сосредоточивая внимание на конкретном, практическом наблюдении за некоторыми из них, я чувствую вдохно-

\footnotetext{
52 Соляная монополия оказалась внутренним источником дохода для них. Помимо этого, во многих местностях основаны опиумные, шёлковые и полотняные фактории, удобно расположенные для ведения торговли.

53 Со времени основания Палаты уполномоченных по делам Индии Корона пользуется правом утверждения (selection) генерал-губернатора, предложенного Компанией.
}

вение при мысли, что в Европе усердно поощряется литература, широко распространяются знания, что почти в совершенном состоянии находится механика, ежедневно прогрессирует политика, и в целом соблюдаются с образцовой точностью моральные обязанности, невзирая на искушения, свойственные состоянию высокой и роскошной изысканности, и что распространяется религия, - даже среди скептицизма и фальшивой философии.

Я постоянно на протяжении ряда лет прилагал усилия к тому, чтобы посетить Западный мир, чтобы на личном опыте убедиться в этом. Я, наконец, преуспел в преодолении обстоятельств, препятствующих моей цели - преимущественно личного характера; и, отплыв из Калькутты 19 ноября 1830 года, я прибыл в Англию 8 апреля следующего года. Подробности моего путешествия можно будет найти в дневнике, который я намерен издать; - вместе со всем, что показалось мне наиболее достойным упоминания и записи в отношении рассудка, нравов и обычаев, и особенно о добродетелях и выдающихся качествах женщин, живущих в этой стране.

Вопрос о возобновлении Хартии Почтенной Ост-Индской компании ${ }^{54}$ находится сейчас на рассмотрении правительства и разных лиц, связанных с Индией, опрашивают на эту тему в качестве экспертов; власти пожелали, чтобы и я в качестве местного жителя этой страны представил своё свидетельство, которое и будет, следовательно, предложено на следующих страницах [25].

Хотя это и будет опубликовано вместе с другими заметками со свидетельствами, представленными Избранному Комитету Палаты Общин, я полагаю верным опубликовать его отдельно, с целью предпослать эти предварительные объяснения и сопроводить их заметками и ответами на замечания, сделанные по этому поводу лицами, чьи мнения заслуживают упоминания.

\section{Примечания переводчика:}

[1] ...Ассамом, Кассеем и Араканом - Ассам область у подножия Восточных Гималаев, долина Брахмапутры (с 1950 г. один из штатов республики Индия). Англичане присоединили Ассам к своим владениям в результате Первой англо-

\footnotetext{
${ }^{54}$ Хартия Компании в последний раз возобновлялась Короной в 1813 г. с некоторыми усовершенствованиями, на период двенадцати лет, и соответственно действует вплоть до 1833, если её не возобновят прежде этого срока.
} 
бирманской войны 1824-1826. Кассей - одно из названий Манипура (ныне один из штатов республики Индия). Аракан - территория на югозападе Бирмы, захваченная англичанами в ходе Первой англо-бирманской войны. С первых веков нашей эры до 1785 г. Аракан был отдельным государством. моря.

[2] ...Западного моря - т. е. Аравийского

[3] Обширные пространства этой империи - Раммохан употребляет слово «империя» для обозначения Индии до появления понятия «Британская Индийская империя» во 2-й половине XIX века после установления коронного правления в 1858; смысловая нагрузка слова «империя» по контексту абзаца оказывается не столько политической, сколько философской: Индия как «империя духа», объединённая «общими религиозными принципами», т. е. верой, дхармой.

[4] Калидаса - (V в. н. э.) выдающийся поэт Древней Индии, автор ряда поэм и драм на санскрите.

[5] Ману - легендарный прародитель человеческого рода, которому приписывают авторство сборника «Законы Ману» («Манавадхармашастра»), детально регламентирующего правила поведения для людей всех варн (сословий).

[6] Химават и Виндхья- оригинальное название Гималаев, восходящее к имени мифического царя гор Хималая, отца богини Парвати / Умы, супруги бога Шивы.

[7] Арьяварта - (букв. «путь, страна, земля ариев») Великая Северо-индийская равнина, изначальная территория расселения племён ариев, пришедших в Индию с северо-запада в середине ІІтысячелетия до н. э. Арии считали земли Арьяварта ритуально чистыми и священными благодаря осуществляемым на ней ведическим ритуалам и жертвоприношениям, а территории за горами Виндхья и Сатпура на Юге - чуждой себе (Дакшинапатха, или современный Декан). Поэтому Раммохан называет её «культурной и священной землёй» и поясняет значение слова “Арьяварта" как “земля, населённая достойными людьми”. В оригинальном тексте «Законов Ману» этого пояснения нет (См. Законы Ману. Пер. с санскр. С. Д. Эльмановича, провер. и испр. Г. И. Ильиным. М.: Эксмо, 2002. C. 43).

[8] Ср. в русском переводе: «Страну, созданную Богами, которая [лежит] между божествен- ными реками Сарасвати и Дришадвати, называют Брахмавартой» (Законы Ману... С. 42).

[9] Раджмахал, Бихар, Бенарес, провинции Аллахабада и Мальвы, до северного берега Нербудды... - Раджмахал - горы в Восточной Индии ныне в штате Джаркханд; Бихар - область в нижней части Средне-Гангской равнины, примыкающая на севере к Непалу. Бенарес - искажённое англизированное название города Варанаси (Каши), одного из древнейших городов Индии на берегу Ганга (ныне в штате Уттар-Прадеш). Почитается индуистами как священное место. Аллахабад - (санскр. Праяг) крупный город на Средне-Гангской равнине, место слияния Ганги, Джамны и мифической реки Сарасвати, крупный центр индуистского паломничества. Мальва - Плато в Центральной Индии. Нербудда - искажённое английское название реки Нармада.

[10] Млеччха- древнее санскритское название для народов, отличавшихся от ариев по верованиям и культуре; первоначально применялось к автохтонным индийским племенам и народам, позже, по мере ассимиляции последних ариями - ко всем чужакам, иностранцам, не соблюдавших законов дхармъ.

[11] Рагхунандана - бенгальский законовед XIV в.

[12] Империи Суфиев - по всей видимости, Раммохан Рай имеет в виду персидское государство Сефевидов (1501-1736) - династии, возводившей свою генеалогию к суфию Сафиад-Дину (1252-1334), возглавившему движение против монгольских правителей Хулагуидов.

[13] Около 900 лет тому назад... (Газни, Гхор и Афган) - Раммохан Рай обозначает время первых мусульманских вторжений от первых набегов в Северо-Западную Индию правителей Газни (Афганистан), однако первые тюркские вторжения в Синд датируются 712 годом.

[14] Газни, Гхор, Афган - Раммохан употребляет неточные названия мусульманских правителей и династий. Газни - имя тюркского правителя г. Газны Махмуда (II в.), совершившего десять походов в Северную и Западную Индию и нещадно истреблявшего индусов и разрушавшего их храмы. Его государство ограничивалось территорией Синда и Мултана; при преемниках Газни династия быстро пала. Гхор, или Гур - имя полководца Мухаммада Гури (XI - XII в.), завоевавшего Северную Индию и назначившего наместником Дели своего военачальника Кутб-удДина Айбека, наследники которого (династия 


\section{Исторический журнал: научные исследования № 5 (17) • 2013}

DOI: $10.7256 / 2222-1972.2013 .5 .9064$

Гулямов) правили до 1290 г. Афган - имеется в виду династия Хилджи, основанная афганским военачальником Фероз-шахом (1290-1296).

[15] Бабур - завоеватель, потомок Чингисхана (а не Тамерлана, как пишет Раммохан Рай), вторгшийся в Индию из Афганистана в 1526 г. и основавший в Дели новую династию Моголов. Его династия (Могольская)правила Империей Великих Моголов и называлась так благодаря монгольскому происхождению своего основателя.

[16]...под власть англичан - К моменту написания Раммоханом Раем «Краткого очерка» во владении Ост-Индской компании были Бенгалия (в т. ч. Бихар), Южная Индия (Мадрасское президентство), Западная (Бомбейское президентство) и Центральная (Северо-Западная провинция).

[17] Ранджит Сингх - (1780-1839) основатель сикхского государства в Панджабе. Коронован в 1801; проводил политику военного и политического усиления своего государства, что, по сути, подготовило его к войне с Ост-Индской компанией. Сикхи, которых Раммохан Рай называет «племенем» - одна из религиозных общин Индии, последователи религии сикхизма (от «сикх»- ученик), основанной в XV в. последователями проповедника гуру Нанака, который утверждал веру в Единого Бога, лишённого зримого образа, мистическую любовь к Богу (бхакти), выступал против засилья брахманов и кастовой системы.

[18] Акбар II - номинальный правитель Дели, бывшей столицы империи Великих Моголов (а не Тимуридов (потомков Тимура - Тамерлана), как его именует Раммохан Рай).

[19] ...от императора Хиндустана (Джахангира) - Основанная в 1600 г., Ост-Индская компания в Индии добилась торговых привилегий от императора Джахангира из династии Великих Моголов, и боролась с португальскими и голландскими конкурентами. Когда Джахангир в 1612 г. узнал о том, что англичане, которым он благоволил, разбили португальскую флотилию у Сурата, он предоставил им в 1613 г. торговые привилегии, чтобы противопоставить их португальцам, а также право организовать факторию в Сурате.

[20] Брюс «Анналы»... - Джон Брюс (17541826) секретарь Лондонского Контрольного совета (См. примечание [21]), автор двухтомного исторического труда «Анналы Ост-Индской компании: от основания Хартией королевы Елиза- веты в 1600 до союза Лондона и Английских ОстИндских компаний 1707-1708». (1810, «Annals of the Honorable East-India Company: from Their Establishment by the Charter of Queen Elizabeth, 1600 to the Union of the London and the English East India Companies 1707-8»).

...Андерсон «История коммерции»- Адам Андерсон (1692 (1693 ?) - 1765) - шотландский әкономист, авторкниги «Историческое и хронологическое описание происхождения коммерции от ранних свидетельств до настоящего времени, содержащее историю общих коммерческих интересов Британской Империи» (1762, «Historical and Chronological Deduction of the Origin of Commerce from the Earliest Accounts to the Present Time, containing a History of the Great Commercial Interests of the British Empire»).

...cэр Томас Роу Журнал и письма - Томас Роу (1581-1644) - английский политик периода царствований Елизаветы и Карла I; в 16151618 г. был послом при дворе могольского императора Джахангира, у которого добился привилегий для основания английской фактории в $\mathrm{Cy}$ рате. «Дневник миссии в Могольской империи» («Journal of the Mission to the Moghul Empire») T. Роу стал одним из важных исторических источников по истории правления Джахангира.

...Рейналь «Восточная и Западная Индии» - Томас Гийом Рейналь (1713-1796) - французский учёный и писатель эпохи Просвещения. Автор труда «История двух Индий» (1770, «l'Histoire des Deux Indes»).

...Орм «Исторические фрагменты» и о правительстве и народе Индостана, - Роберт Орм (1728-1801), служащий Ост-Индской компании, историк. Раммохан Рай имеет в виду его труд «Исторические фрагменты о Могольской империи, Маратхах и английских интересах в Индостане с 1659 года» (1781, «Historical Fragments of the Mogul Empire, the Morattoes and English Concerns in Indostan from 1659»), изданный в качестве дополнения к большому трёхтомному труду «История военных операций британской нации в Индостане с 1745 года» (1763-1778, «A History of the Military Transactions of the British Nation in Indostan from 1745»).

...Доу «История» - Александр Доу (1735$1779)$ - офицер на службе Ост-Индской компании, учёный-ориенталист. Раммохан отсылает к его переводу труда индийского мусульманского историка Фаришты (1560-1620) «История Индостана, переведённая с персидского и написанная Фариштой» (1768, «History of Hindostan, translat- 
ed from the Persian of Ferishta»). Помимо этого Доу принадлежат труды об истории Могольской империи до конца правления Аурангзеба - «Происхождение и природа деспотизма в Хиндустане» («On the Origin and Nature of Despotism in Hindostan») и «Исследование состояния Бенгалии» («An Enquiry into the State of Bengal»).

...Малколм «Очерк политической истории Индии» и его же «Центральная Индия»Джон Малколм (1769-1833) - государственный деятель и историк, почётный доктор Оксфордского университета. Занимал крупные посты в Ост-Индской компании. Впоследствии написал ряд ценных трудов по истории Индии. Раммохан Рай отсылает читателей к «Воспоминаниям о Центральной Индии» (1823, «Memoir of Central India») и книге «Политическая история Индии с 1784 по 1823» (1823, «Political History of India from 1784 to $1823 »)$.

...Милль «История Британской Индии» Джеймс Милль (1773-1836) - шотландский философ-утилитарист, один из отцов классической политәкономии, политический мыслитель и историк. Работал в лондонской штаб-квартире ОстИндской компании и никогда в Индии не бывал. В 1818 г. вышла его трёхтомная «История Британской Индии» («The History of British India»), которая выдержала множество изданий и стала настольной книгой теоретиков имперской колониальной политики. Книга Милля носит скорее обобщающий, нежели эмпирико-описательный характер; за что многократно подвергалась критике индийскими мыслителями от младших современников Раммохана Рая до экономиста, нобелевского лауреата Амартья Сена (р. 1933).

[21] Палата уполномоченных (точнее, Палата уполномоченных по делам Индии, или Контрольный совет) - Согласно принятому в 1784 акту Питта, сохраняя неприкосновенность власти Ост-Индской компании, юридически был учреждён Контрольный совет для наблюдения за действиями директоров Ост-Индской компании по основным политическим вопросам, и Секретный комитет из трёх директоров
Компании, подчинённый Контрольному совету. Именно Контрольный совет в метрополии стал превращаться в ведомство по делам Индии.

[21] Палата уполномоченных (или Контрольный совет) - Согласно принятому в 1784 акту Питта, сохраняя неприкосновенность власти Ост-Индской компании, юридически был учреждён Контрольный совет для наблюдения за действиями директоров Ост-Индской компании по основным политическим вопросам, и Секретный комитет из трёх директоров Компании, подчинённый Контрольному совету. Именно Контрольный совет в метрополии стал превращаться в ведомство по делам Индии.

[22] до 1793 г. - с этого времени маркиз Корнуоллис внёс изменения в юридическую и налоговую системы, приблизив их к британским аналогам. В 1793 г. был проведён закон о том, что все должности и посты в аппарате управления, которые приносят доход свыше 500 фунтов стерлингов в год, могут занимать только служащие Компании, приносившие присягу. Это было сделано для того, чтобы исключить возможность занятия индийцами ответственных и значимых должностей.

[23] Корнуоллис Чарлз - (1738 - 1805) представитель аристократической семьи герцога Корнуоллиса, член Палаты Лордов, генерал-губернатор Бенгалии с 1786 года. Ввёл систему налогообложения в Бенгалии, известную как «Постоянное землеустройство» (Permanent settlement, $1793)$ провёл реформу судебной системы и другие организационно-административные изменения.

[24] ..основную часть этого труда, а именно обзор практического действия этих систем - имеются в виду ответы Раммохана на вопросы о судебной системе, системе налогообложения в Индии, а также о состоянии народа Индии: «Ответы на вопросы о состоянии судебной системы Индии», «Ответы на вопросы о состоянии системы налогообложения» и р«Дополнительные вопросы о состоянии народа Индии».

[25] См. предыдущее примечание.

\section{Библиография:}

1. Альбедиль М. Ф. Индия: беспредельная мудрость. М., 2005. С. 24.

2. Банерджи Сурендронатх. Исследование индийской истории / Перевод с английского Т. Г. Скороходовой // Вопросы философии. 2012. № 9. С. 144-156.

3. Ванина Е. Ю. Исторический обзор // Индия: страна и её регионы. Под ред. Е. Ю. Ваниной. М., 2000. С. 12-38.

4. Ванина Е. Ю. Средневековое мышление: индийский вариант. М., 2007. 


\section{Исторический журнал: научные исследования № 5 (17) • 2013}

DOI: $10.7256 / 2222-1972.2013 .5 .9064$

5. Рай Раммохан. Дар верующим в единого Бога. Перевод с английского, примечания Т. Г. Скороходовой // Вопросы философии. 2010. № 11. С. 159-168.

6. Рашковский Е. Б. Научное знание, институты науки и интеллигенция в странах Востока XIX-XX вв. М., 1990.

7. Скороходова Т. Г. Бенгальское Возрождение. Очерки истории социокультурного синтеза в индийской философской мысли Нового времени. СПб., 2008.

8. Скороходова Т. Г. Историческое сознание Бенгальского Возрождения (историко-философский анализ) // Восток. 2009. № 1. С. 76-87

9. Скороходова Т. Г. “Паломничество в страну Запада” в опыте мыслителей Бенгальского Ренессанса // Вопросы философии. 2011. № 11. С. 163-173.

10. Скороходова Т. Г. Младобенгальцы. Очерки истории социальной мысли Бенгальского Возрождения (Первый период, 1815-1857). СПб., 2012.

11. Скороходова Т. Г. Раммохан Рай, родоначальник Бенгальского Возрождения (Опыт аналитической биографии). СПб., 2008.

12. Тагор Р. Собрание сочинений в 12-ти тт. М., 1961-1964. Т. XI.

13. ТойнбиА. Дж. Цивилизация перед судом истории. М. - СПб., 1996.

14. Bhattacharjee K. S. The Bengal Renaissance: Social and Political Thought. New Delhi, 1986.

15. Collet S. D. (and Stead F. H.) The Life and Letters of Raja Rammohun Roy / Ed. by D. K. Biswas and R. Ch. Ganguli.3rd ed. Calcutta, 1962.

16. Dasgupta Subrata. The Bengal Renaissance: Identity and Creativity from Rammohun Roy to Rabindranath Tagore. Delhi, 2007.

17. Justyński Janusz. Mysl Spoleczna i Politiczna Renesans u Indyiskiego, od Rama Mohana Raya do Rabindranata Tagora. Warszawa etc., 1985.

18. Halbfass W. India and Europe.An Essay of Philosophical Understanding.Albany, 1988.

19. Kopf D. British Orientalism and Bengal Renaissance.Berkeley, 1969.

20. Kopf D. BrahmoSamaj and Making of Modern Indian Mind.Princeton, 1979.

21. Petition of Akbar II, Mughal Emperor of Delhi // Collet S. D. The Life and Letters of Raja Rammohun Roy / Ed. by D. K. Biswas and R. Ch. Ganguli.3rd ed. Calcutta, 1962.P. 480-485.

22. Poddar A. Renaissance in Bengal. Quests and Confrontations.1800-1860.Simla, 1970.

23. Poddar A. Renaissance in Bengal. Search for Identity. 1860-1919.Simla, 1977.

24. Roy Raja Rammohun. The English Works / Ed. by J.C. Ghose. In 4 vols.New Delhi, 1982.

25. Sarkar Susobhan. Bengal Renaissance and Other Essays.New Delhi, etc., 1970.

\section{References:}

1. Al'bedil' M. F. Indiya: bespredel'naya mudrost'. M., 2005. S. 24.

2. Banerdzhi Surendronatkh. Issledovanie indiiskoi istorii / Perevod s angliiskogo T. G. Skorokhodovoi // Voprosy filosofii. 2012. № 9. S. 144-156.

3. Vanina E. Yu. Istoricheskii obzor // Indiya: strana i ee regiony. Pod red. E. Yu. Vaninoi. M., 2000. S. 12-38.

4. Vanina E. Yu. Srednevekovoe myshlenie: indiiskii variant. M., 2007.

5. Rai Rammokhan. Dar veruyushchim v edinogo Boga. Perevod s angliiskogo, primechaniya T. G. Skorokhodovoi // Voprosy filosofii. 2010. № 11. S. 159168.

6. Rashkovskii E. B. Nauchnoe znanie, instituty nauki i intelligentsiya v stranakh Vostoka XIX-XX vv. M., 1990.

7. Skorokhodova T. G. Bengal'skoe Vozrozhdenie. Ocherki istorii sotsiokul'turnogo sinteza v indiiskoi filosofskoi mysli Novogo vremeni. SPb., 2008.

8. Skorokhodova T. G. Istoricheskoe soznanie Bengal'skogo Vozrozhdeniya (istoriko-filosofskii analiz) // Vostok. 2009 . № 1. S. 76-87

9. Skorokhodova T. G. "Palomnichestvo v stranu Zapada” v opyte myslitelei Bengal'skogo Renessansa // Voprosy filosofii. 2011. № 11. S. 163-173.

10. Skorokhodova T. G. Mladobengal'tsy. Ocherki istorii sotsial'noi mysli Bengal'skogo Vozrozhdeniya (Pervyi period, 1815-1857). $\mathrm{SPb} ., 2012$.

11. Skorokhodova T. G. Rammokhan Rai, rodonachal'nik Bengal'skogo Vozrozhdeniya (Opyt analiticheskoi biografii). SPb., 2008.

12. Tagor R. Sobranie sochinenii v 12-ti tt. M., 1961-1964. T. XI.

13. Toinbi A. Dzh. Tsivilizatsiya pered sudom istorii. M. - SPb., 1996. 


\section{Междисциплинарные исследования}

DOI: $10.7256 / 2222-1972.2013 .5 .9064$

14. Bhattacharjee K. S. The Bengal Renaissance: Social and Political Thought. New Delhi, 1986.

15. Collet S. D. (and Stead F. H.) The Life and Letters of Raja Rammohun Roy / Ed. by D. K. Biswas and R. Ch. Ganguli. 3rd ed. Calcutta, 1962.

16. Dasgupta Subrata.The Bengal Renaissance: Identity and Creativity from Rammohun Roy to Rabindranath Tagore. Delhi, 2007.

17. Justyński Janusz. Mysl Spoleczna i Politiczna Renesansu Indyiskiego, od Rama Mohana Raya do Rabindranata Tagora. Warszawa etc., 1985.

18. Halbfass W. India and Europe. An Essay of Philosophical Understanding. Albany, 1988.

19. Kopf D. British Orientalism and Bengal Renaissance. Berkeley, 1969.

20. Kopf D. Brahmo Samaj and Making of Modern Indian Mind. Princeton, 1979.

21. Petition of Akbar II, Mughal Emperor of Delhi // Collet S. D. The Life and Letters of Raja Rammohun Roy / Ed. by D. K. Biswas and R. Ch. Ganguli. 3rd ed. Calcutta, 1962. P. 480-485.

22. Poddar A. Renaissance in Bengal. Quests and Confrontations.1800-1860. Simla, 1970.

23. Poddar A. Renaissance in Bengal. Search for Identity. 1860-1919. Simla, 1977.

24. Roy Raja Rammohun. The English Works / Ed. by J.C. Ghose. In 4 vols. New Delhi, 1982.

25. Sarkar Susobhan. Bengal Renaissance and Other Essays. New Delhi, etc., 1970 